Огляди літератури, оригінальні дослідження, погляд на проблему, ювілеї

УДК 616.12-008.331.1-06:616.12-005.8-085

DOI 10.11603/1811-2471.2019.v0.i1.10059

\title{
КОМПЛАЄНС ДО ЛІКУВАННЯ ХВОРИХ З АРТЕРІАЛЬНОЮ ГІПЕРТЕНЗІЄЮ ТА ІШЕМІЧНОЮ ХВОРОБОЮ СЕРЦЯ В АМБУЛАТОРНИХ УМОВАХ
}

\author{
๑Н. В. Пасєчко, Л. В. Радецька, Н. І. Ярема, А. О. Боб, І. В. Смачило, А. І. Хоміцька \\ ДВНЗ «Тернопільський державний медичний університет імені І. Я. Горбачевського МОЗ України»
}

РЕзЮМЕ. У статті розглядаються актуальні питання формування комплаєнсу (прихильності) до лікування пацієнтів із гіпертонічною хворобою (ГX) та ішемічною хворобою серця (IXC). Оцінюється необхідність взаємодії лікарів і пацієнтів при вирішенні проблем, пов'язаних із недостатнім комплаєнсом до проведеної медикаментозної терапії.

Мета-проаналізувати прихильність до лікування (комплаєнс) в амбулаторнихумовахухворихз артеріальною гіпертензією та ішемічною хворобою серця та шляхи її підвищення.

Матеріал і методи. Обстежено 182 пацієнти, які побували на прийомі у сімейного лікаря або кардіолога. Усіх обстежених поділили на 2 групи. Пацієнтам 1 групи - із низькою прихильністю до лікування - проводили стандартний амбулаторний моніторинг артеріального тиску з періодичними оглядами у первинному центрі медико-санітарної медичної допомоги, а також застосовували метод автоматичного щоденного телефонного нагадування щодо необхідності регулярного приймання ліків. Пацієнтам 2 групи - із високим комплаєнсом до лікуванння - телефонних нагадувань не проводили. Прихильність до терапії оцінювали за допомогою спеціалізованого опитувальника Моріски-Гріна.

Результати. Оцінка динаміки комплаєнсу на початку дослідження, через 1 та 2 місяці показала, що кількість прихильних до терапії пацієнтів збільшилася як у групі з телефонним нагадуванням, так і в групі пацієнтів без нагадування. Аналіз балів за тестом Моріски-Гріна показав, що комплаєнс у 1 групі мав значно кращу динаміку. Наприкінці всього періоду спостереження відмічено достовірне зниження рівня артеріального тиску в обох групах, однак ступінь зниження був вираженішим у пацієнтів 1 групи.

Висновок. Отримані дані дослідження спонукають зробити висновок про те, що застосування телефонних нагадувань дозволяє достовірно підвищити прихильність до терапії у пацієнтів із ГX та IXC.

КлючОВІ СлОВА: комплаєнс; прихильність до лікування; регулярність терапії.

Вступ. Гіпертонічна хвороба та ішемічна хвороба серця залишаються однією з головних проблем охорони здоров'я в усьому світі, а пошук шляхів підвищення ефективності їх лікування, спрямованих на зниження ускладнень та смертності, $\epsilon$ актуальним завданням [1]. Як відомо, з 1 квітня 2017 р. в Україні діє урядова програма «Доступні ліки», у рамках якої пацієнти за рецептом лікаря можуть отримати безкоштовно або з доплатою лікарські засоби для лікування серцево-судинних захворювань, цукрового діабету 2 типу та бронхіальної астми [2]. Проте, згідно з даними ВООЗ 2006 р., як мінімум 50 \% пацієнтів не приймають прописані лікарські препарати. За оцінкою практичних лікарів, низька прихильність до терапії (нонкомплаєнс) є основною причиною відсутності досягнення цільового рівня артеріального тиску (АТ) у 70 \% пацієнтів [3]. Для них великою психологічною проблемою залишається необхідність пожиттєвого регулярного приймання ліків та медичного спостереження. На нашу думку, важливе значення у формуванні нонкомплаєнсу у пацієнта має низька інформованість у питаннях лікування та профілактики захворювання.

Мета дослідження - проаналізувати прихильність до лікування та шляхи ії підвищення в амбулаторних умовах у хворих з артеріальною гіпертензією та ішемічною хворобою серця.
Матеріал і методи дослідження. Обстежено 182 пацієнти, які побували на прийомі у сімейного лікаря або кардіолога. У дослідження включені чоловіки і жінки, старші 28 років, із вихідним рівнем офісного систолічного АТ 140-179 мм рт. ст. і діастолічного АТ до 100 мм рт. ст., яким було призначено комбіновану антигіпертензивну терапію згідно з рекомендаціями лікування Європейського товариства кардіологів. Відповідно до критеріїв ESH/ESC [101] усі пацієнти мали високий або дуже високий кардіоваскулярний ризик.

Досліджуваним пацієнтам на початку лікування, через 1 та 2 місяці спостереження проводили загальноклінічне обстеження, включаючи офісне вимірювання АТ, індекс маси тіла, обов'язково реєстрували факт використання антигіпертензивних препаратів.

Усіх обстежених поподілили на 2 групи. Пацієнтам 1 групи (98 осіб, 60 жінок, 38 чоловіків) - із низькою прихильністю до лікування - проводили стандартний амбулаторний моніторинг артеріального тиску з періодичними оглядами у первинних центрах медико-санітарної медичної допомоги, а також застосовували метод автоматичного щоденного телефонного нагадування про необхідність регулярного приймання ліків. Пацієнтам, які відмовлялись від встановлення автоматичного нагадування, застосовували телефон- 
Огляди літератури, оригінальні дослідження, погляд на проблему, ювілеї

не нагадування медсестрою або лікарем (у перший тиждень спостереження - через день, у наступні 2 тижні - 2 рази на тиждень, у подальшому - протягом 2 місяців - щотижня). Крім того, хворим видавали «Пам'ятку пацієнта» з рекомендаціями правил правильного харчування, режиму динамічного фізичного навантаження, ведення щоденника самоконтролю гемодинамічних показників.

Пацієнтам 2 групи - із високим комплаєнсом до лікуванння (62 особи, 43 жінки та 19 чоловіків) телефонні нагадування не проводили. Щодо іншого (частота візитів до лікаря, видача «Пам'ятки пацієнта») методи лікування були однакові у пацієнтів обох груп. Усім хворим рекомендували вести щоденник самоконтролю, який було розроблено спеціально для даного дослідження, з визначенням показників артеріального тиску і пульсу (щоденно), періодично - маси на фоні регулярного приймання медичних середників.

Прихильність до терапії оцінювали за допомогою спеціалізованого опитувальника МоріскиГріна, який валідизований і рекомендований до широкого застосування [4]. Це найпростіший тест оцінки прихильності до терапії. Він складається $з$ 4 запитань: а) забували Ви коли-небудь прийняти препарати? (так - 0, ні - 1); б) чи ставитесь Ви іноді неуважно до часу приймання ліків? (так - 0, ні - 1); в) пропускаєте Ви приймання препаратів, якщо відчуваєте себе добре? (так - 0, не пропускаю - 1); c) якщо Ви відчуваєте себе погано після приймання ліків, то чи не пропускаєте Ви наступне приймання? (так - 0, ні - 1). Пацієнт повинен самостійно відповідати на запитання, вибираючи один із 2-х варіантів відповідей. Кожну відповідь оцінюють в 1 бал. При обробці підраховують сумарний бал. Прихильним до терапії вважають пацієнта, який відповів «ні» на всі 4 питання. Хворих, які набрали 3 бали, вважають недостатньо прихильними, і вони перебувають у групі ризику розвитку нонкомплаєнсу. Хворих, які набрали 2 бали і менше, вважають не прихильними до лікування. Даний метод дозволяє оцінити вихідну прихильність пацієнтів, а також динаміку цього показника у процесі дослідження.

Статистичну обробку даних проводили за допомогою пакета програм SAS (версія 6.12). При аналізі розраховували середні величини (M), їх стандартні помилки (m). Достовірність середніх величин оцінювали за критерієм Стьюдента (t). Результати вважали достовірними при $\mathrm{p}<0,05$.

Результати й обговорення. Базові характеристики пацієнтів, яких включено у дослідження, представлено у таблиці 1.

Таблиця 1. Характеристика пацієнтів, включених у дослідження

\begin{tabular}{|c|c|c|c|}
\hline & 1 група & 2 група & $\mathrm{P}$ \\
\hline Кількість пацієнтів & $98(61,1 \%)$ & $62(38,9 \%)$ & 0,0001 \\
\hline Чоловіки/жінки & $38 / 60$ & $19 / 43$ & $0,001 / 0,001$ \\
\hline 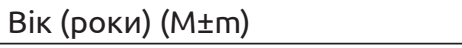 & $63,3 \pm 0,3$ & $62,8 \pm 0,4$ & 0,07 \\
\hline Вперше виявлена АГ (\%) & 6,7 & 9,4 & 0,001 \\
\hline 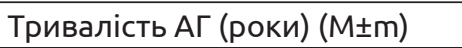 & $11,3 \pm 0,1$ & $12,1 \pm 0,2$ & 0,4 \\
\hline САТ мм рт. ст. $(\mathrm{M} \pm \mathrm{m})$ & $169,0 \pm 0,2$ & $165,4 \pm 0,4$ & 0,0001 \\
\hline 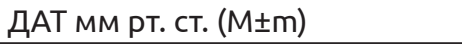 & $98,2 \pm 0,2$ & $96,7 \pm 0,2$ & 0,0001 \\
\hline IMT $\left(\mathrm{K} \Gamma / \mathrm{M}^{2}\right)(\mathrm{M} \pm \mathrm{m})$ & $27,4 \pm 0,1$ & $26,9 \pm 0,1$ & 0,7 \\
\hline $\begin{array}{l}\text { Обтяжений сімейний анамнез } \\
\text { по ССЗ (\%) }\end{array}$ & 52,6 & 53,2 & 0,7 \\
\hline IXC (\%) & 44,5 & 48,6 & 0,01 \\
\hline Цукровий діабет (\%) & 12,9 & 21,6 & 0,001 \\
\hline
\end{tabular}

Із таблиці видно, що кількість пацієнтів із нонкомплаєнсом виявилась значно більшою, ніж пацієнтів із високою прихильністю до терапії $(61,1$ проти 38,9 \% відповідно, р<0,0001). Пацієнти 1 групи були трохи старші, серед них переважали чоловіки ( $<<0,001)$. Рівень АТ (як систолічного, $p<0,0001$, так і діастолічного $p<0,0001)$ у пацієнтів цієї групи був вищий, ніж у 2 групі. Серед пацієнтів 1 групи рідше зустрічались супутні IXC та цукровий діабет. Діагноз вперше виявленої АГ також був у значно меншій кількості випадків серед пацієнтів 1 групи.
Оцінка динаміки комплаєнсу на початку дослідження, через 1 та 2 місяці показала, що кількість прихильних до терапії пацієнтів збільшилася як у групі з телефонним нагадуванням (з 13 до 57 \%), так і в групі пацієнтів без нагадування (з 11 до 28 \%). Аналіз балів за тестом Моріски-Гріна показав, що комплаєнс у 1 групі мав значно кращу динаміку (рис. 1).

На антигіпертензивну терапію відповіли всі пацієнти. Цільовий рівень АТ (за класифікацією ВОО3, <140/90 мм рт. ст.) був досягнутий у 77 \% пацієнтів першої групи та 59 \% пацієнтів 2 групи. 
Огляди літератури, оригінальні дослідження, погляд на проблему, ювілеї

Наприкінці всього періоду спостереження відмічено достовірне зниження рівня АТ в обох групах, однак ступінь зниження був вираженішим у паці- єнтів 1 групи (рис. 2), у яких через 2 місяці терапії зареєстровано достовірне зниження середньодобового САТ і ДАТ за рахунок дії препаратів.

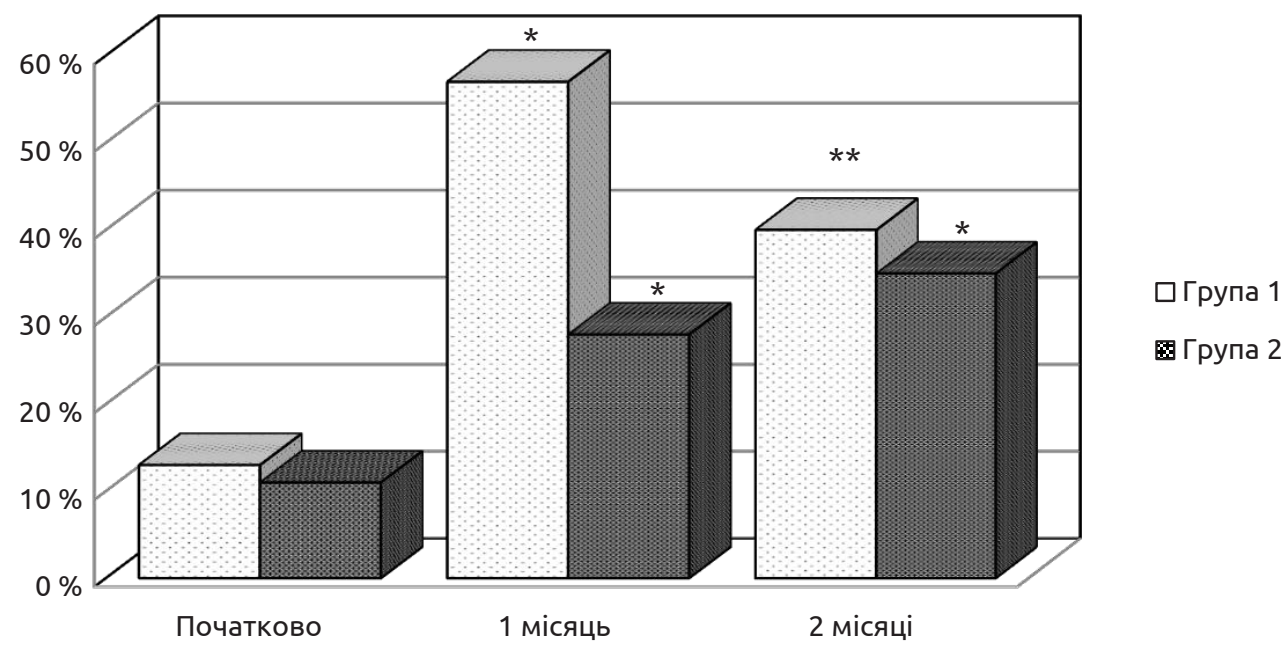

Рис. 1. Прихильність до терапії у процесі спостереження в 1 та 2 групах.

Примітка. ** - p<0,00001 порівняно з початком лікування, * - p<0,002 порівняно з початком лікування.

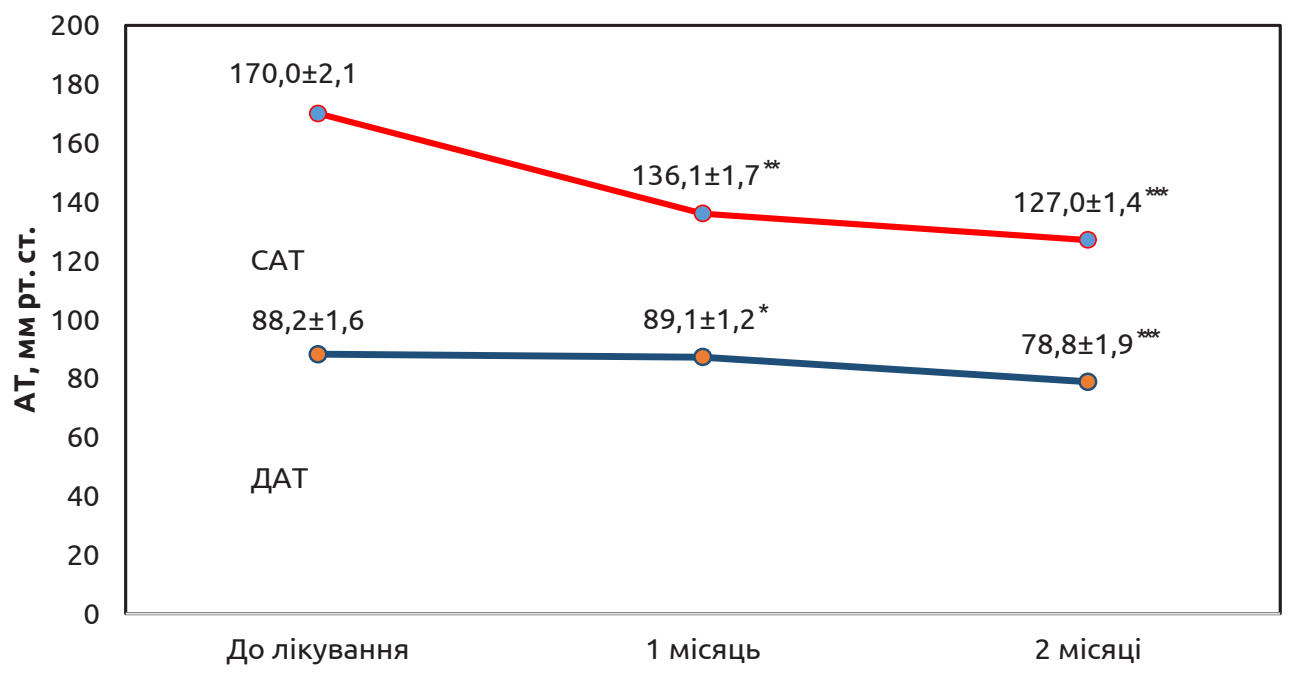

Рис. 2. Динаміка офісного АТ протягом 2 місяців лікування пацієнтів 1 групи.

Примітка. * - $p<0,05 ; * *-p<0,02 ; * * *-p<0,001$.

Пацієнти, яким проводили телефонне нагадування, ретельніше вели щоденник самоконтролю, більшість із них відмічала, що такі нагадування надавали їм значну психологічну підтримку.

Отже, отримані дані дослідження спонукають зробити висновок про те, що застосування телефонних нагадувань дозволяє достовірно підвищити прихильність до терапії у пацієнтів із ГX та IXC.

Висновки. 1. Основна частка пацієнтів із ГХ та IXC не прихильна до лікування, що істотно підвищує загрозу тяжких наслідків.

2. Формування комплаєнсу у хворих $\epsilon$ багатофакторним процесом, найважливішими шляхами його підвищення $\epsilon$ поліпшення процесу лікування, а також психологічного впливу на хворого.

Перспективи подальших досліджень. Пропоновані підходи досить ефективні, але проблема низької прихильності до терапії як була, так і залишається, якщо не зростає в останні роки. Ми пропонуємо застосувати комплексний підхід, який би об'єднав традиційні методи (які потребують удосконалення) і нові технологічні методи підвищення прихильності до терапії. Можливо, з урахуванням психологічного чинника, слід розглядати і командний підхід (лікуючий лікар і психіатр/психоневролог) у проблемі прихильності до терапії. 
Огляди літератури, оригінальні дослідження, погляд на проблему, ювілеї ЛІТЕРАТУРА

1. $2013 \mathrm{ESH} / \mathrm{ESC}$ Guidelines for the management of arterial hypertension: 234 The Task Force for the management of arterial hypertension of the European Society of Hypertension (ESH) and of the European Society of Cardiology (ESC) // Eur. Heart J. - 2013. - Vol. 34. - P. 2159-2219.

2. dn_20180803_1446 (pdf, 51 K6)

3. Carter $\mathrm{S}$. A question of choice - compliance in medicine taking, a preliminary review / S. Carter, D. Taylor, R. Le-

venson. - London: University of London School of pharmacy, 2001. - Available at: www.medicinespartnership.org Accessed 04 Dec 2012.

4. Morisky D.E. Concurrent and predictive validity of a self-reported measure of medication adherence / D. E. Morisky, L. W. Green, D. M. Levine // Med. Care. - 1986. Vol. 24. - P. 67-74.

\section{REFERENCES}

1. (2013). ESH/ESC Guidelines for the management of arterial hypertension: 234 The Task Force for the management of arterial hypertension of the European Society of Hypertension (ESH) and of the European Society of Cardiology (ESC). Eur. Heart J., 34, 2159-2219.

2. dn_20180803_1446 (pdf, $51 \mathrm{~K} 6)$

3. Carter, S., Taylor, D., \& Levenson, R. (2001). A ques- tion of choice - compliance in medicine taking, a preliminary review. London: University of London School of pharmacy. Retrieved from: www.medicinespartnership. org Accessed 04 Dec 2012.

4. Morisky, D.E., Green, L.W., \& Levine, D.M. (1986). Concurrent and predictive validity of a self-reported measure of medication adherence. Med. Care, 24, 67-74.

\title{
КОМПЛАЕНС К ЛЕЧЕНИЮ БОЛЬНЫХ С АРТЕРИАЛЬНОЙ ГИПЕРТЕНЗИЕЙ И ИШЕМИЧЕСКОЙ БОЛЕЗНЬЮ СЕРДЦА В АМБУЛАТОРНЫХ УСЛОВИЯХ
}

\author{
๑Н. В. Пасечко, Л. В. Радецкая, Н. И. Ярема, А. О. Боб, И. В. Смачило, А. И. Хомицкая
}

ГУВЗ «Тернопольский государственный медицинский университет имени И. Я. Горбачевского

\author{
МОЗ Украины»
}

PЕЗЮМЕ. В статье рассматриваются актуальные вопросы формирования комплаенса (приверженности) к лечению пациентов с гипертонической болезнью (ГБ) и ишемической болезнью сердца (ИБС). Оценивается необходимость взаимодействия врачей и пациентов при решении проблем, связанных с недостаточным комплаенсом к проводимой медикаментозной терапии.

Цель - проанализировать приверженость к лечению (комплаенс) в амбулаторных условиях у больных с артериальной гипертензией и ишемической болезнью сердца и пути ее повышения.

Материал и методы. Обследовано 182 пациента, побывавших на приеме у семейного врача или кардиолога. Все обследованные были разделены на 2 группы. Пациентам 1 группы - с низкой приверженностью к лечению - проводили стандартный амбулаторный мониторинг артериального давления с периодическими осмотрами в первичном центре медико-санитарной медицинской помощи, а также применяли метод автоматического ежедневного телефонного напоминания о необходимости регулярного приема лекарств. Пациентам 2 группы - с высоким комплаенсом - телефонные напоминания не проводились. Приверженность к терапии оценивалась с помощью специализированного опросника Мориски-Грина.

Результаты. Оценка динамики комплаенса в начале исследования, через 1 и 2 месяца показала, что количество приверженных к терапии пациентов увеличилось как в группе с телефонным напоминанием, так и в группе пациентов без напоминания. Анализ баллов по тесту Мориски-Грина показал, что комплаенс в 1 группе имел значительно лучшую динамику. В конце всего периода наблюдения отмечено достоверное снижение уровня артериального давления в обеих группах, однако степень его снижения была более выраженной у пациентов 1 группы.

Вывод. Полученные данные исследования побуждают сделать вывод о том, что применение телефонных напоминаний позволяет достоверно повысить приверженность к терапии у пациентов с ГБ и ИБС.

КЛЮЧЕВЫЕ СЛОВА: комплаенс; приверженность к лечению; регулярность терапии. 
Огляди літератури, оригінальні дослідження, погляд на проблему, ювілеї

\title{
COMPLIANCE FOR THE TREATMENT OF PATIENTS WITH ARTERIAL HYPERTENSION AND CORONARY HEART DISEASE IN OUTPATIENT CARE
}

\author{
@N. V. Pasyechko, L. V. Radetska, N. I. Yarema, A. O. Bob, I. V. Smatchylo, A. I. Homitska \\ I. Horbachevsky Ternopil State Medical University
}

SUMMARY. The article deals with topical issues of the formation of compliance to the treatment of patients with hypertension and coronary heart disease. The necessity of interaction between doctors and patients in the solution of some problems connected with insufficient compliance to the medical therapy is estimated.

The aim - to analyze the compliance of treatment in outpatient care in patients with arterial hypertension and coronary heart disease and ways to increase it.

Material and Methods. There were examined 182 patients who visited a family doctor or cardiologist. All the patients were divided into 2 groups. For the patients in the group 1 with low compliance to the treatment it was performed standard outpatient care with blood pressure monitoring with periodic reviews at the primary health care center, and also used the method of automatic daily telephone reminders for regular medication consumption. Patients in the group 2 - with high compliance to the treatment, telephone reminders were not conducted. The compliance to the therapy was evaluated using the Morisky-Green Specialized Questionnaire.

Results and Discussion. The assessment of the compliance dynamics at the beginning of the study, after 1 and 2 months, showed that the number of patients with compliance to the therapy increased both in the telephone reminder group and in the group of patients without reminders. The analysis of the Morisky-Green test points showed that the compliance in the group 1 had much better dynamic. At the end of the entire observation period, there was a significant decrease in blood pressure levels in both groups, however, the degree of decline was more pronounced in patients in the group 1.

Conclusion. The obtained research data suggest that the use of telephone reminders can significantly increase the compliance to the therapy in patients with arterial hypertension and coronary heart disease in outpatient care.

KEY WORDS: compliance to the treatment; regularity of the therapy. 